\title{
Studies in the Miliuseae. V. Review of the taxonomic history of a polyphyletic 'tribe'
}

\author{
J.B. Mols and P.J.A. Keßler
}

\begin{abstract}
J.B. Mols E P.J.A. Keßler (Nationaal Herbarium Nederland, Universiteit Leiden Branch, P.O. Box 9514, 2300 RA Leiden, The Netherlands. Email: Mols@NHN.LeidenUniv.NL) 2003. Studies in the Miliuseae. Review of the taxonomic history of a polyphyletic 'tribe'. Telopea 10(1): 113-124. This article addresses the problem of the classification of the genera in the Annonaceae. The former classifications within the family based on subsets of morphological data are not congruent with each other and cannot be used to make a clear and uniform classification of the family or subsets of genera. This problem is illustrated here for the tribe Miliuseae Hook.f. \& Thomson, which has been defined by a special stamen type (miliusoid) uncommon in the Annonaceae. It is argued that this tribe is not monophyletic and is not "recognised" as such in the classifications using different morphological data sets. The polyphyly of the tribe is also indicated by preliminary molecular studies. Future studies, combining molecular and morphological data, are outlined.
\end{abstract}

\section{Introduction}

The Annonaceae Juss. are a pantropical family consisting of about 130 genera and 2300 species. Most of the species occur primarily in tropical lowland rainforest. The family is often represented by high numbers of individuals and species. In Asia alone about 60 genera and about 1000 species can be found.

The Annonaceae are clearly delimited (e.g. Fries 1959; Keßler 1993) and are regarded monophyletic in all studies including those based on molecular data (Qiu et al. 2000). In contrast to distinct family boundaries, the classification on subfamilial level is unresolved. The genera in the Annonaceae are notoriously difficult to define and to classify into "natural groups". Over the years different authors have subdivided the family into formal and informal groups based on several character sets, such as pollen, flowers, fruits, etc. (e.g. Hutchinson 1923, 1964; Sinclair 1955; Fries 1959; Walker 1971; Setten \& Koek-Noorman 1992; Heusden 1992; Keßler 1993; Koek-Noorman et al. 1997). A comparison of these classifications reveals a diversity of conflicting conclusions.

The problem of the classification within the Annonaceae is here illustrated by discussing the position of the genera included in the tribe Miliuseae Hook.f. \& Thomson (sub Saccopetaleae) according to Keßler (1993), namely Alphonsea Hook.f. \& Thomson, Mezzettia Becc., Mezzettiopsis Ridl., Miliusa A.DC., Orophea Blume, Phoenicanthus Alston and Platymitra Boerl. Various alternative character sets that might delimit the tribal boundaries are also discussed. This article is one of a series of studies on this tribe. In previous publications in this series the tribal name Saccopetaleae (articles I-IV) has been used, but a study of the nomenclature has revealed that the correct name should be Miliuseae. This tribe has been chosen as it is the object of the Ph.D. study of the first author. 


\section{Miliuseae}

The first time the Annonaceae were subdivided was by Dunal (1817). At the time only eight genera (excluding Kadsura Juss., now placed in the Schisandraceae) were recognised and, based on fruit characters only, were classified into three groups.

The tribe Miliuseae was first described by Hooker and Thomson in 1855 in their Flora Indica and included the genera Miliusa, Saccopetalum Benn. (= Miliusa), and Alphonsea. The circumscription of the tribe was based on the following characters: carpels free, petals valvate, stamens loosely imbricate and anthers visible in flower (not concealed). The authors stressed that the tribe differs from the other tribes in the structure of the stamens. In present day taxonomy of the family, this type of stamen is referred to as the miliusoid stamen. Generally the stamens in the Annonaceae are characterized by being narrowly oblong to oblanceoloid with a short filament, two thecae and a shieldlike apical prolongation of the connective (Fig. 1) (Heusden, 1992). In the miliusoid stamen this apical prolongation is not shield-like and is either small-discoid and not extending over the anthers or absent (Fig. 2). The same characters used by Hooker and Thomson are still used to define this tribe. Keßler (1993) recognises a Miliusa-group based on sepals and petals being valvate, stamens and carpels few, and connective without a prolonged specialized apex.

The Miliuseae sensu Keßler includes six (seven in the original publication) genera which can be determined using the following key and diagnostic descriptions.

\section{Key to the genera in the Miliuseae}

1a. Outer and inner petals of (almost) equal length 2

b. Outer petals much smaller than inner petals .......................................................... 5

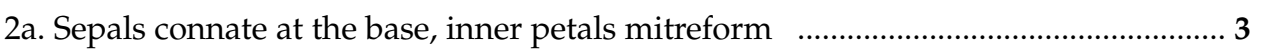

b. Sepals free, inner petals not mitreform ................................................................... 4

3a. Stamens 6 or 9, ovule(s) 1-2, monocarps up to $1 \mathrm{~cm}$ in diameter .. Phoenicanthus

b. Stamens 20-35, ovules c. 10, monocarps 1 to $5 \mathrm{~cm}$ in diameter ............. Platymitra

4a. Inner petals saccate at the base, stamens 15-60, carpel(s) 1-15, monocarps stipitate Alphonsea

b. Inner petals not saccate at the base, stamens 9-21, carpel 1, monocarps sessile ...... Mezzettia

5a. Sepals and outer petals similar in size and shape 6

b. Sepals and outer petals similar in shape but outer petals much larger, inner petals clawed at base Orophea (incl. Mezzettiopsis)

6a. Sepals free, inner petals saccate, glandular tissue along middle vein .. Miliusa s.s.

b. Sepals connate at the base, inner petals not saccate, glandular ring at base 


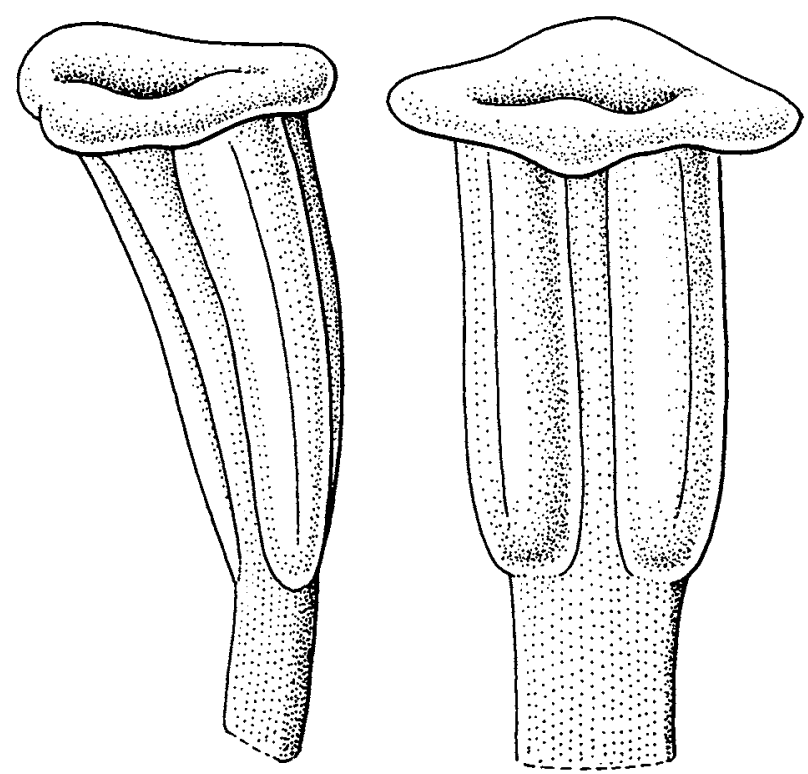

Fig. 1. Stamens of Phaeanthus nutans Hook.f. \& Thomson (KEP/FRI 12307 (Whitmore)). Drawing from Mols \& Keßler (2000) by J. van Os.

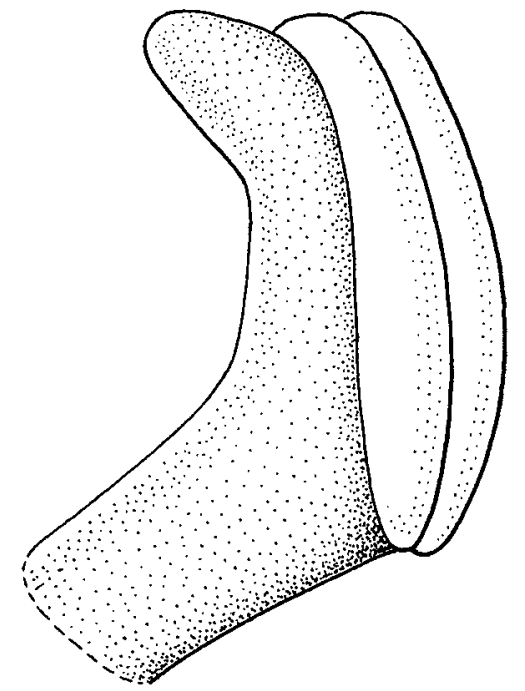

Fig. 2. Stamen of Miliusa velutina (Dunal) Hook.f. \& Thomson (Kerr 1078). Drawing from and by Heusden (1992) (sub Miliusa villosa) redrawn and adapted by J. van Os. 
Alphonsea Hook.f. \& Thomson, Fl. Ind. 1: 152 (1855).

Trees or shrubs; flowers bisexual; sepals 3; petals 6, subequal, inner petals slightly saccate at the base; stamens 15-60, miliusoid; carpel(s) 1 to 15; ovules few, biseriate; monocarps globose to cylindrical, stipitate. Twenty-five species found from mainland Asia (India, Thailand) to Indonesia and the Philippines. Recently revised by Keßler (1996).

Mezzettia Becc., Nuovo. Giorn. Bot. Ital. 3: 187 (1871).

Trees; flowers bisexual; sepals 3; petals 6, inner petals shorter than outer petals; stamens 9-21, miliusoid with truncate dilated apex; carpel 1; ovules 2, biseriate; monocarps globose, sessile. Four species found from Peninsular Malaysia to the Moluccas. Recently revised by Heijden and Keßler (1990). Doubtfully included in the Miliuseae sensu Keßler.

Miliusa A.DC., Mem. Anon. (preprint): 37 (1832).

Shrubs or trees; flowers bisexual or unisexual; sepals 3; petals 6, outer petals similar to sepals, inner petals much longer and saccate at the base; stamens few to numerous, miliusoid; carpels few to numerous; ovule(s) 1-10, biseriate; monocarps globose to oblong, stipitate. About 25 to 30 species from mainland Asia (India, China) to New Guinea and Australia. Several species previously included in Miliusa differ from the general perception of the genus. The main differences are that the inner petals bases are not saccate in these species but are thickened forming a glandular ring, the sepals are slightly connate at the base and the leaf bases are amplexicaule. These species are thought to form a new genus (to be described) and are referred to in the key as Miliusa p.p.. The species of the Flora Malesiana area and Australia have recently been revised (Mols and Keßler, in prep.).

Orophea Blume, Bijdr. Fl. Ned. Ind.: 18 (1825).

Small trees; flowers bisexual; sepals 3; petals 6, inner petals longer than outer ones, inner petals clawed or spoon-shaped; stamens 3-12, miliusoid; carpels 3-18; ovule(s) 1- 6, uni- or biseriate; monocarps globose or cylindrical, stipitate. Fifty species subdivided into two subgenera Orophea and Sphaerocarpon (latter includes former genus Mezzettiopsis Ridl., Kew Bull.: 389 (1912)). Found from mainland Asia (India, China) to the Sunda Islands and the Philippines. The genus has been revised by Keßler (1988a, 1990) and Leonardia and Keßler (2001).

Phoenicanthus Alston in Trimen, Handb. Fl. Ceylon 6: 6 (1931).

Trees; flowers bisexual; sepals 3, slightly connate; petals 6, subequal, inner petals mitreform and concave at the base; stamens 6 or 9 , miliusoid with obtuse apex; carpel(s) 1-3; ovule(s) 1-2; monocarps globose, sessile. Two species endemic to Ceylon (Huber, 1985).

Platymitra Boerl., Cat. Pl. Phan. 1: 33 (1899).

Trees; flowers bisexual, ramiflorous; sepals 3, connate at base; petals 6 , subequal, inner petals mitreform; stamens 20-35, miliusoid; carpel(s) 1-3; ovules 10, biseriate; monocarps globose to ovoid, sessile. Two species found from Thailand to Java and the Philippines. The genus has been revised by Keßler (1988b). 


\section{Classifying the Miliuseae}

In the next paragraphs and accompanying Table 1 the position of each genus in the tribe in twelve classifications is shown. These twelve classifications are not all that are known for the family, but are the most widely used or of particular interest in the study of the Miliuseae. The classifications are not always easy to compare because in some cases a genus is missing from a classification simply because it had not been described at the time, did not occur in the area the treatment was dealing with, or because no sufficient data were available. If a genus has been placed in synonymy the most recent circumscription of the accepted genus is recognised.

Reichenbach 1837: After the work by Dunal (1817), the number of genera in the family rose sharply to twenty-four (including some non-Annonaceous genera). The Annonaceae (sub Annoneae) were treated as a tribe of the Ranunculaceae, and based on flower characters primarily three groups were recognised: the Cardiopetaleae, Guatterieae and Annonariae, with the latter group subdivided into three smaller groups, Uvarieae, Bocageae, Annoneae genuinae. The only members of the Miliuseae sensu Keßler known up to this point were Miliusa and Orophea, placed in the Cardiopetaleae because the petals were united at the base in Miliusa (in the type specimen, discovered to be genetically atypical, the inner petals were united in some flowers).

Endlicher 1839: Endlicher dealt with a similar number of genera, but the tribal division was somewhat different. Based also on stamen and carpel characters three tribes were recognised: Bocageae, Xylopieae and Annoneae with several genera not allocated to any of these three tribes. The main difference with Reichenbach's system was that the two Miliuseae genera were now placed in the Bocageae, based on having a finite number of stamens. A first indication of the problems concerning the classification was already shown here. The genus Hyalostemma, placed in Miliusa in modern classifications, could not be accommodated under Endlicher's system.

Hooker and Thomson 1855: As mentioned before, the tribe Miliuseae was first established in the Flora Indica. Based on flower characters alone, Hooker and Thomson recognised six tribes: Annoneae, Uvarieae, Miliuseae (sub Saccopetaleae), Mitrephoreae, Xylopieae and Guatterieae. This classification was based on the plants occurring in India and predominantly dealt with the Asian Annonaceae. But many of the tribal names and characters adopted have been used in later stages as a precursor for the general classification of the Annonaceae. The Miliuseae, defined as having free carpels, valvate petals, and imbricate, miliusoid stamens consisted of Miliusa, Saccopetalum (= Miliusa), and Alphonsea. The only other genera of Miliuseae sensu Keßler classified by Hooker and Thomson were Orophea and Phoenicanthus (sub Orophea obliqua). These genera were placed in the Mitrephoreae, which was defined by having free carpels, valvate petals, inner petals clawed at the base, stamens densely packed together and anthers concealed. This last character state did not apply to Orophea and Phoenicanthus. The clawed base of the inner petals of Orophea (and Phoenicanthus) was the reason this genus was placed in the Mitrephoreae, but the stamen characters suggest it should have been placed in the Miliuseae.

Hooker and Thomson 1872: Only slight variations were made from the previous treatment. Five tribes were recognised with the Annoneae included in the Xylopieae. The genus Guatteria Ruiz \& Pav. was no longer recognised as Asiatic, and the tribe Guatterieae had been renamed Unoneae. The description of the Miliuseae was modified slightly to allow for the fact that the petals could be valvate or imbricate. The stamen characters were again thought to be of more importance and so Orophea and Phoenicanthus (as Bocagea obliqua and B. coriacea) were included in the tribe. Additionally, the genus Lonchomera Hook.f. \& Thomson was first described and placed in the Miliuseae, this genus is now considered a synonym for Mezzettia. This meant that 


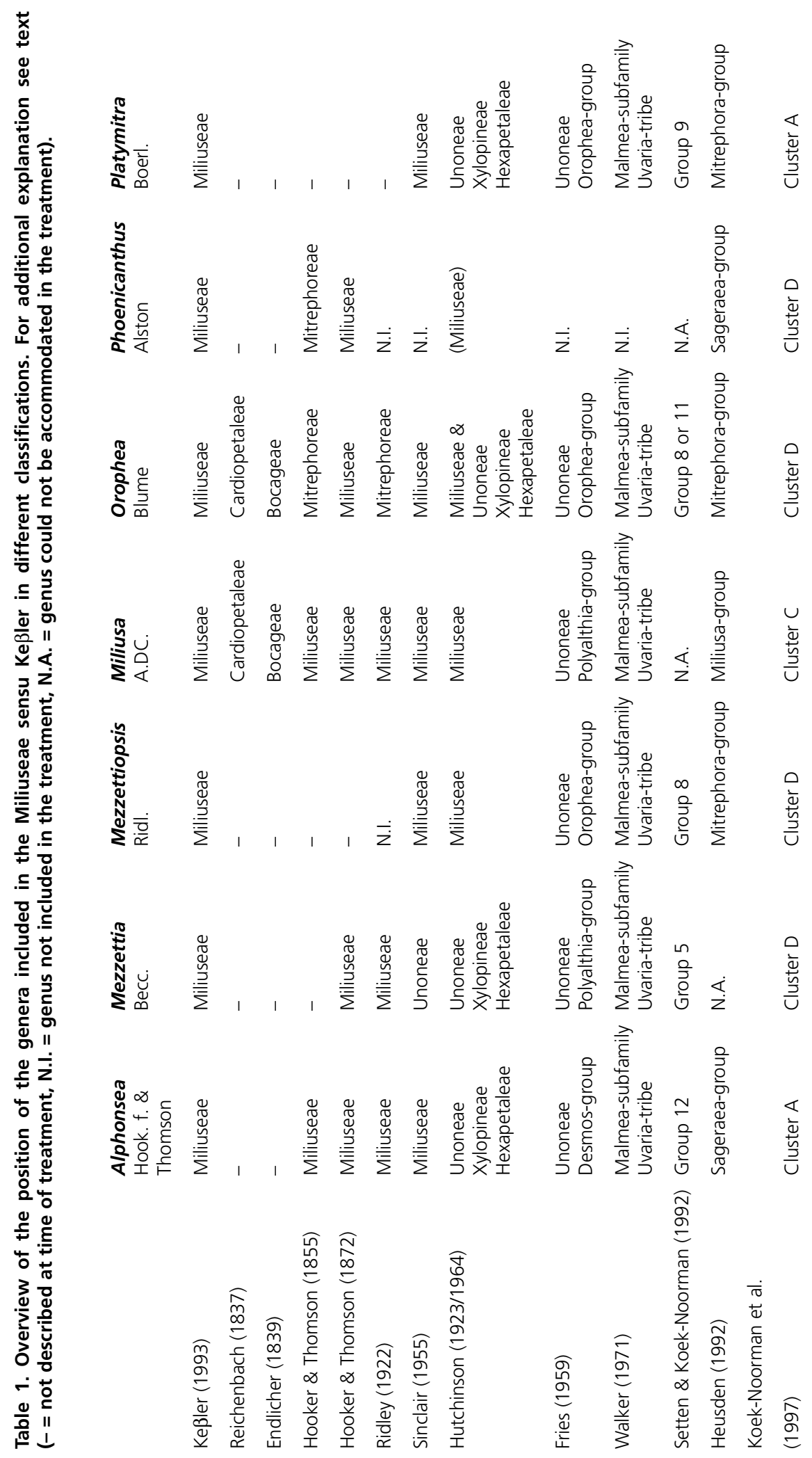


all in all five of seven genera included in the Miliuseae sensu Keßler were placed in this tribe, with the other two not yet recognised or described. The genus Dendrokingstonia (Hook.f. \& Thomson) Rauschert (sub Kingstonia Hook.f. \& Thomson), with imbricate sepals and petals was included in the tribe. This genus is now usually regarded as related to the genus Uvaria L. and allies.

Ridley 1922: In his treatment of Malayan Annonaceae Ridley recognised the same tribes as Hooker and Thomson based on mostly the same floral characters. The main difference was that Ridley again put the emphasis on petal shape instead of the stamens when dealing with Orophea and placed it back in the Mitrephoreae. The miliusoid stamen was in fact not mentioned as a defining character for the Miliuseae that included Miliusa, Alphonsea, Mezzettia and Dendrokingstonia (sub Kingstonia). Ridley included Phaeanthus Hook.f. \& Thomson in the Miliuseae because it also had small sepals and outer petals and large inner petals, this difference between the two whorls of petals becoming the main character to place all genera together. In Mezzettia this difference is only slight, the inner petals often being smaller than the outer.

Sinclair 1955: This treatment dealt also only with the Annonaceae of the Flora of Peninsular Malaysia, but is regarded as one of the main references dealing with Asian Annonaceae as it is the most complete overview of the family in the region. The tribes used were the same as Ridley's with a slight difference in the composition of the tribes. Platymitra had been described in the meantime and was added to the tribe. Furthermore Sinclair stated (p. 175) that the stamen characters are probably better suited to be used than the corolla characters to base the relationships between the genera in the Miliuseae, this in contrast with the other tribes. He thought that sexual organs are more likely to be static and less liable to variation over time. For this reason Orophea was transferred (back) to the Miliuseae, and Sinclair noted that, based on petal structure, Orophea and Platymitra were considered to be closely linked to the Mitrephoreae. The stamens of Mezzettia on the other hand were not regarded to be miliusoid and the genus was transferred to the Unoneae. The stamens of Mezzettia are slightly different as the apex is truncately dilated, but presently are regarded by us to be more related to the miliusoid type than any other.

Hutchinson 1923 \& 1964: Hutchinson (1923) used the ideas of Hooker and Thomson for the entire family (nearly 100 genera and more than 1000 species). But using the same characters for all Annonaceae genera resulted in an artificial classification. Hutchinson recognised two subfamilies Annonoideae and Monodoroideae. Within the Annonoideae three tribes Uvarieae, Miliuseae and Unoneae were recognised. The latter was divided into two subtribes Annonineae and Xylopineae, the latter of which was divided into three series Hexapetalae, Tetrapetalae and Tripetalae (group A, B, and C in Hutchinson, 1964). Miliusa, Orophea and Mezzettiopsis were in the Miliuseae based on the valvate petals and a large differentiation between the inner and outer petals together with the Asian genera Phaeanthus, Trivalvaria Miq., Marsypopetalum Scheff., the American genera Heteropetalum Benth. and Cymbopetalum Benth. as well as the African genera Piptostigma Oliv. and Brieya De Wild. (now included in Piptostigma). The genera Mezzettia, Platymitra and Alphonsea were placed in the Unoneae, subtribe Xylopineae, series Hexapetalae, based on having 6 petals, the outer petals similar or larger than the inner petals and free carpels. The miliusoid stamen character was only used to define the genera Mezzettiopsis, Miliusa, Orophea and Saccopetalum. This classification is artificial because Orophea was placed in two tribes, the Miliuseae and the Unoneae, subtribe Xylopineae, series Hexapetalae. The 1964 treatment only differed by the addition of some (not all!) newly described genera. To the Miliuseae Fenerivia Diels (Africa) and Anomianthus Zoll. (Asia) were added, with the latter placed also in the tribe Uvarieae. 
Fries 1959: This treatment is generally seen as the standard work of the Annonaceae on a global scale. It is based primarily on floral characters, but more characters were used, probably producing a better classification, especially for the South-American genera, as Fries revised almost all the Neotropical species known at that time. Fries also recognised two subfamilies: the Annonideae and the Monodoroideae. The Annonideae were subdivided into three tribes and 15 groups, the Uvarieae (with 5 groups), the Unoneae (with 9 groups), and the Tetramerantheae. All genera now in the tribe Miliuseae sensu Keßler, based on having valvate petals, were placed in the Unoneae but subdivided into three groups. Miliusa and Mezzettia were placed in the Polyalthia-group with eight other genera. This group was recognised based on having petals in 2 whorls, flowers having bracts, apocarpous fruits, inner petals not enclosing the sexual organs and touching each other at the base, and axillary inflorescences. Orophea (including Mezzettiopsis) and Platymitra were placed in the Orophea-group, which, although similar to the Polyalthia-group, differed in having inner petals that enclose the sexual organs being fused at the tip to form a dome. In this group twelve additional genera were included. The genus Alphonsea was placed in the Desmosgroup together with four other genera. This group differs from the Polyalthia-group in having leaf-opposed inflorescences. As can be concluded from this short summary the interpretation of the characters is different and some are used at another level as in previous treatments.

Walker 1971: Walker introduced a major change in the general classification trend within the family. He used pollen morphology to classify the Annonaceae into three subfamilies, the Malmea, Fusaea and Annona subfamilies. The first and last of these subfamilies were subdivided further; the Malmea subfamily into three tribes, the Malmea tribe, Uvaria tribe and Guatteria tribe, and the Annona subfamily into four tribes, Hexalobous tribe, Asimina tribe, Annona tribe and Cymbopetalum tribe. The Miliuseae were placed in the Uvaria-tribe which was defined by having solitary globose pollen grains which are apolar, radiosymmetric and inaperturate of mediumsize to large with well-developed to reduced columellae and often verrucate exine. Based on these characters the tribe included c. 60 genera, including all genera in the Miliuseae sensu Keßler (except Phoenicanthus which was not included in the treatment).

Setten and Koek-Noorman 1992: These authors studied fruit and seed characters, and recovered 16 groups from the observed variation patterns. This suggested a different set of relationships among the genera. Unfortunately only four of seven genera in the Miliuseae sensu Keßler were accommodated in these groups. Mezzettia was placed in group 5 because it has large monocarps with two lateral seeds with thick walls and stout lamellate ruminations in often more than 4 parts. Mezzettiopsis (= Orophea) was placed in group eight based on a low number of pitted lateral seeds with spiniform ruminations. This group was said to be closely related to the genus Polyalthia and the members of group 9. This latter group included Platymitra and was different from 8 in having its seeds in 2 rows. Alphonsea was accommodated in group 12 which was defined by having lamellate rumination in four parts with a smooth seed wall and having no oil cells in the endosperm. This group was also said to be closely related to Polyalthia. Phoenicanthus was not accommodated, as data available was not sufficient to suggest any placement. Fruit and seed characters are very diverse in Miliusa and Orophea. Orophea was found to consist of two sections one of which could be placed in group 8 (together with Mezzettiopsis) and the other in group 11. Miliusa was so diverse that the authors did not accommodate the genus, but proposed it should be placed in the centre of the scheme connecting the groups, together with Polyalthia, with which it also shares some features. 
Heusden 1992: In this study the flower characters were partly reevaluated, new characters were used and the significance of more traditional characters to the classification of the genera was reinterpreted. Nineteen groups were recognised and the members of the Miliuseae sensu Keßler were distributed across three groups. Mezzettia could not be accommodated in any of the nineteen groups. Miliusa was included in the Miliusa-group along with Marsypopetalum and Phaeanthus. The sepals and outer petals being of similar size and shape characterized this group. The author indicated that this group was closely related to the Mitrephora-group, which included the genera Orophea, Mezzettiopsis, and Platymitra, and was defined by valvate sepals, two whorls of petals that are of slightly different size and shape and mostly several lateral ovules. The genera Alphonsea and Phoenicanthus were placed in the Sageraeagroup based on a large number of broadly defined characters. Heusden also stated that this group was ill-defined but the genera could not be placed better in any group other than together. Some connection was shown with the Miliusa-group as Alphonsea has similar stamens and carpels to the genera in this group. The author concluded that the groups could be recognised only through a combination of several character states but in many instances the genera did not fall neatly into any particular group.

Koek-Noorman et al. 1997: This study combined the two previous datasets and performed a cluster analysis on the data thus making it the first treatment to use both flower and fruit/seed characters to group the genera within the family. The phenetic analysis clustered Alphonsea and Platymitra together in group A. Miliusa was placed in group C forming in this group a cluster with Mitrephora (Blume) Hook.f. \& Thomson and Desmopsis Saff. All other genera in the Miliuseae sensu Keßler were placed in group D, along with Phoenicanthus (based on flower characters only) and Mezzettia, and Orophea and Mezzettiopsis closely also clustering together.

This comparison of earlier classifications clearly shows that when switching the emphasis from one character (state) or data set to another the composition of resulting groups or tribes changes considerably. Our conclusions are therefore similar to those of Koek-Noorman et al. (1990). No single character set gives a clear picture of the relationships of the genera within the family. One needs to combine the different datasets (e.g. fruit, pollen, flower, etc.) into a complete data set, which should be used in a phylogenetic analysis. Doyle and Le Thomas (1994, 1996) performed such an analysis of 79 morphological characters. This data set produced 180 most parsimonious trees belonging to two islands, which showed a high level of homoplasy, and therefore the relationships between the groups obtained remained unclear. However in the rooting of these cladograms and in the formation of the major clades the pollen characters were phylogenetically most informative. This idea was strengthened in their later studies (Doyle and Le Thomas, 1997) because of the phylogenetic differences found between the cladograms before and after removal of the pollen data from the overall morphological data set in the analysis. It must be stated that their studies only included c. 36 out of 130 genera of the Annonaceae worldwide, which means that many possibly morphologically intermediate genera were omitted. Because only one genus (Miliusa) of the Miliuseae sensu Keßler was included this study has not been used in the previous comparison of classifications. 


\section{Preliminary ideas based on molecular data}

In recent years research has been more directed towards the use of molecular data to determine relationships within the family. Zuilen (1996) was the first to use molecular data but she only dealt with one genus in the family. Bygrave (2000) and Chatrou et al. (in prep.) have made phylogenetic analyses based on respectively $r b c \mathrm{~L}$ and $r b c \mathrm{~L} \&$ trnL-F DNA sequence data. Although many of the groupings found are not well supported and the overall resolution of parts of the cladograms obtained is rather poor, the cladograms have shown some interesting aspects. When dealing with such a "primitive" family within the angiosperms, the closest relative of a certain genus might not be found on the same continent. For instance, a close relative of the Asiatic genus Miliusa appears to be the Central American genus Sapranthus Seeman. Classifications on a regional scale will not identify these possible relationships. The importance of this has already been referred to by other authors (e.g. Setten \& KoekNoorman 1992; Heusden 1992; Koek-Noorman et al. 1997; Keßler 1993).

Furthermore even though the resolution in the end clades is poor, these early molecular studies provide a basis for future research. They indicate larger subsets of genera that can be the subjects of further research into the relationships between these genera. A preliminary phylogenetic analysis based on $r b c \mathrm{~L}$ and $t r n \mathrm{~L}-\mathrm{F}$ DNA sequence data (Chatrou et al., in prep.) suggests that the Miliuseae sensu Keßler are not monophyletic and that the closest relatives of Miliusa might be any of the following genera: Fitzalania F.Muell., Ancana F.Muell., Sapranthus, Neo-uvaria Airy Shaw, Sageraea Dalzell, Enicosanthum Becc., Alphonsea, Platymitra, Phaeanthus, Popowia Endl. and Polyalthia Blume p.p. Of these genera only Alphonsea and Platymitra are included in the Miliuseae sensu Keßler and all genera except Sapranthus have an Asiatic distribution. Only some Polyalthia species ended up in this clade. The few species of Polyalthia included (c. 10 of 150) in the analyses (Bygrave, 2000; Chatrou et al., in prep.) were divided over several clades. Not surprisingly the genus Polyalthia is regarded as polyphyletic, because based on morphology alone it was already considered to be an ill-defined genus.

In none of the classifications examined and surveyed above, is the molecular grouping of these twelve genera closest to Miliusa suggested or found. For instance different stamen types can be found (miliusoid, various stamens with a shield-like prolongation of the connective, etc.), some genera have two whorls with similar petals, while others have similar sepals and outer petals, and also the fruits come in many different shapes and sizes.

To solve this question a combined analysis of molecular and morphological data needs to be performed. Doyle et al. (2000) performed such analysis by combining Bygrave's $r b c \mathrm{~L}$ data and Doyle and Le Thomas' morphological data. In their article the morphological characters were plotted on the cladogram based on the $r b c \mathrm{~L}$ data and the datasets were combined and phylogenetically analyzed. Only the taxa included in the studies by Doyle and Le Thomas were used, all other genera studied by Bygrave were omitted. Of the possible relatives of Miliusa based on the work by Chatrou et al. (in prep.) mentioned previously, Ancana, Sapranthus, several Polyalthia species and Miliusa itself were included. The combined analysis showed a better resolution than the cladogram based solely on molecular data and Miliusa, Sapranthus, Ancana and several Polyalthia species ended up in one clade (the miliusoids) in the consensus cladogram of each of the three islands. This corroborates the preliminary ideas based on the work by Chatrou et al. (in prep.). When looking at the morphological characters it seems that the pollen characters again are phylogenetically most informative. It would be interesting to see whether the other genera thought to be closely related to Miliusa would also end up in this miliusoid clade based on morphology and molecular data. 


\section{Conclusions}

From the evidence presented here, it is clear that classifications of the Annonaceae, based on subsets of morphological data are not satisfactory as they do not recognise monophyletic groups unambiguously. In debating the status of the tribe Miliuseae it seems evident that the Miliuseae as variously recognised by different authors is not a monophyletic group, which also seems to be supported by the molecular data. It is envisaged that the tribe in the present circumscription of Keßler does not comprise a natural group.

In order to find out which morphological characters are phylogenetically informative one must not look at the subsets of morphological data independently but rather combine them to a complete data set, preferably supplemented with molecular data. Within the Annonaceae several such studies are now being carried out.

In our further studies we will keep a focus on the genera included in the tribe Miliuseae sensu Keßler. By using molecular data we want to establish whether this tribe is really polyphyletic. For this purpose a number of genera will be included (up to 30, from Asia, Central-America and Africa) apart from the genera included in the Miliuseae. Based on the work by Bygrave (2000) we will select which genera are the most relevant in elucidating the relationships. If the tribe is really polyphyletic we will then further study the clade containing the genus Miliusa s.s., because this genus has recently been studied morphologically by the authors (Mols \& Keßler, in prep.). In this further study on the Miliusa-clade more taxa will be added, from Miliusa as well as related genera, and when needed, additional genes will be sequenced. At the same time a morphological data set will be constructed for the genera included in the Miliusa-clade by combining the available morphological subsets supplemented with additional data scored from literature and by a survey of herbarium collections. By combining the molecular data set and the complete morphological data set (when congruent), and performing a combined phylogenetic analysis we hope to find which morphological characters (states) are phylogenetically most informative. This information might then be used in further revealing the relationships between the Annonaceae as a whole.

\section{Acknowledgments}

The senior author would like to acknowledge the organizers of the $5^{\text {th }}$ International Flora Malesiana Symposium for the opportunity to present a paper and a poster. The Alberta Mennega Foundation, the Foundation Hugo de Vries and the Netherlands Foundation for the Advancement of Tropical Research (WOTRO) are kindly acknowledged for financial support. Finally special thanks go to Jan van Os and Ben Kieft for making and scanning the drawings on such short notice. Special thanks go to the anonymous reviewer for his extensive and valuable comments on the contents and text.

\section{References}

Bygrave, P.C. (2000) Molecular systematics of Annonaceae Juss. (Preliminary Ph.D. thesis: University of Reading).

Chatrou, L.W., Bygrave, P.C., Mols, J.B., Oosterhof, J.S., Keßler, P.J.A., Pirie, P.C., Erkens, R.H.J., Chase, M.W. \& Hart, H. 't (In prep.) Molecular phylogenetics of Annonaceae based on plastid rbcL and trnL-F DNA sequences.

Doyle, J.A., P.C. Bygrave \& Le Thomas, A. (2000) Implications of molecular data for pollen evolution in Annonaceae. Pp. 259-284 in Harley, M.M., Morton, C.M. \& Blackmore, S. (eds) Pollen and spores: Morphology and biology. (Royal Botanical Gardens: Kew). 
Doyle, J.A. \& Le Thomas, A. (1994) Cladistic analysis and pollen evolution in Annonaceae. Acta Botanica Gallica 141 (2): 149.170.

Doyle, L.A. \& Le Thomas, A. (1996) Phylogenetic analysis and character evolution in Annonaceae. Bulletin du Muséum National d'Histoire Naturelle, 4e série, Section B, Adansonia 18: 279-334.

Doyle, L.A. \& Le Thomas, A. (1997) Significance of palynology for phylogeny of Annonaceae: experiments with removal of pollen characters. Plant Systematics and Evolution 206: 133-159.

Dunal, M.F. (1817) Monographie de la famille des Annonacées. (Treuttel \& Würtz: Paris).

Endlicher, S. (1839) Genera plantarum secundum ordines naturalis disposita. (Fr. Beck: Wien).

Fries, R.E. (1959) Annonaceae. Pp. 1-171 in Engler, A. and Prantl, K. (eds) Die natürlichen Pflanzenfamilien. edn 2, 17a, IIB (Duncker \& Humblot: Berlin).

Heijden, E. van der Keßler, P.J.A. (1990) Studies on the tribe Saccopetaleae (Annonaceae) III. Revision of the genus Mezzettia Beccari. Blumea 35: 217-228.

Heusden, E.C.H. van (1992) Flowers of Annonaceae: morphology, classification and evolution. Blumea Supplement 7: 1-218.

Hooker, J.D. \& Thomson, T. (1855) Flora Indica vol. I (W. Pamplin: London).

Hooker, J.D. \& Thomson, T. (1872) Annonaceae. Pp. 45-94 in Hooker, J.D. The Flora of British India vol. I (L. Reeve \& Co.: London).

Huber, H. (1985) Annonaceae. Pp. 1-75 in Dassanayake, M.D. \& Fosberg, F.R. (eds) A revised handbook to the Flora Ceylon, Vol. V (Amarind Publishing Co. Pvt. Ltd.: New Delhi).

Hutchinson, J. (1923) Contribution towards a phylogenetic classification of flowering plants II. The genera of Annonaceae. Kew Bulletin 7: 241-261.

Hutchinson, J. (1964) The genera of flowering plants. Dicotyledons, Vol. I (Clarendon Press: Oxford).

Keßler, P.J.A. (1988a) Revision der Gattung Orophea Blume (Annonaceae). Blumea 33: 1-80.

Keßler, P.J.A. (1988b) Studies on the tribe Saccopetaleae (Annonaceae) I. Revision of the genus Platymitra Boerlage. Blumea 33: 471-476.

Keßler, P.J.A. (1990) Studies on the tribe Saccopetaleae (Annonaceae) II. Additions to the Genus Orophea Blume. Blumea 34: 505-516.

Keßler, P.J.A. (1993) Annonaceae. Pp. 93-129 in Kubitzki, K., Rohwer, J.G. \& Bittrich, V. (eds) The families and genera of vascular plants, Vol. II (Springer-Verlag: Berlin).

Keßler, P.J.A. (1996) Studies on the tribe Saccopetaleae (Annonaceae) IV. Revision of the genus Alphonsea Hook.f. \& Thomson. Botanische Jahrbücher für Systematik, Pflanzengeschichte und Pflanzengeographie 118 (1): 81-112.

Koek-Noorman, J., Westra, L.Y.Th. \& Maas, P.J.M. (1990) Studies in Annonaceae XIII. The role of morphological characters in subsequent classifications of Annonaceae: a comparative survey. Taxon 39 (1): 16-32.

Koek-Noorman, J., Setten, A.K. van \& Zuilen, C.M. van (1997) Studies in Annonaceae XXVI. Flower and fruit morphology in Annonaceae. Their contribution to patterns in cluster analysis. Botanische Jahrbücher für Systematik, Pflanzengeschichte und Pflanzengeographie 119 (2): 213-230.

Leonardia, A.A.P. \& Keßler, P.J.A. (2001) Additions to Orophea subgenus Sphaerocarpon (Annonaceae): Revision and transfer of Mezzettiopsis. Blumea 46: 141-163.

Mols, J.B. \& Keßler, P.J.A. (2000) Revision of the genus Phaeanthus. Blumea 45 (1): 205-233.

Mols, J.B. \& Keßler, P.J.A. (In prep.) Studies in the tribe Miliuseae (Annonaceae) VI. The genus Miliusa in the Austro-Malesiana area.

Qiu, Y.L., Lee, J., Bernasconi-Quadroni, F., Soltis, D.E., Soltis, P.S., Zanis, M., Zimmer, E.A., Chen, Z., Savolainen, V. \& Chase, M.W. (2000) Phylogeny of basal angiosperms: Analysis of five genes from three genomes. International Journal of Plant Sciences 161 (6 Supplement): S3-S27.

Reichenbach, H.G.L. (1837) Handbuch des natürlichen Pflanzensystems. (Arnold: Dresden-Leipzig). Ridley, H.N. (1922) The Flora of the Malay Peninsula, Vol. I (L. Reeve \& Co.: London).

Setten, A.K. van \& Koek-Noorman, J. (1992) Fruits and seeds of Annonaceae: morphology and its significance for identification. Bibliotheca Botanica. 142.

Sinclair, J. (1955) A revision of the Malayan Annonaceae. Garden's Bulletin Singapore 14: 149-516.

Walker, J.W. (1971) Pollen morphology, phytogeography and phylogeny of the Annonaceae. Contributions from the Gray Herbarium of Harvard University 202: 1-130.

Zuilen, C.M. van (1996) Patterns and affinities in the Duguetia alliance (Annonaceae). Molecular and morphological studies. (Ph.D. Thesis: Utrecht University). 